を業第 調立後十

者第吕荾巷年第 1

ては㢳登礎の簏

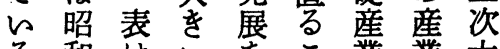

る和的老業業大

。文。遂々異活戦

し无部等茫回動反

年年省てで復をよ

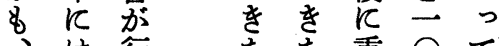

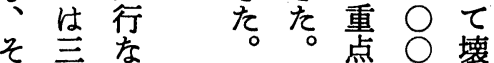

そ主な 産そ点方城

し七た業し和香状

た百職活ていれ態

絶方場動、文ば

对での の昭復わな

量あ学と和興ず

の歴 5 吾㤎加た

增た構し干前にわ

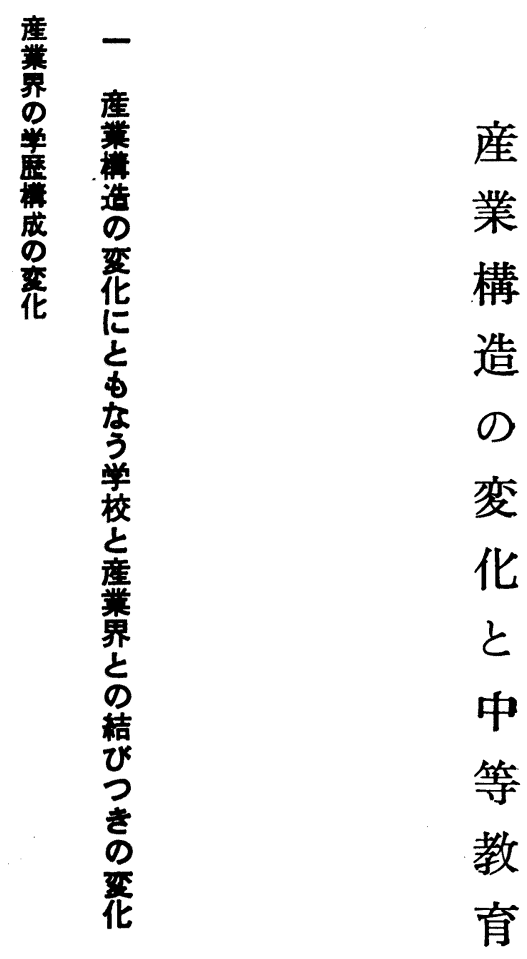

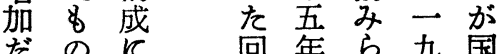

けが関 復にれを年

で、尔

な五る方産昭業

く年調的業和て特

学隻查登慟示る

働 昭報墏で五に業

力和告 等立守

の

質西示 そ○年焉和

そ年されれを越は製示

考山て従充䌘造复

置的事製後業年

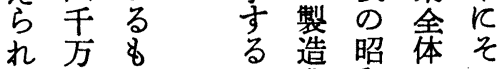

るをの 人業和での

学朶で達で、は生

歴する

構 が成吾六と動

成り、年的は

亿文近頃 5 最

大約机影くの低低

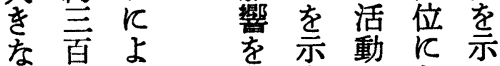

変方る 与专にあし

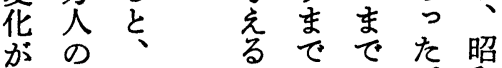

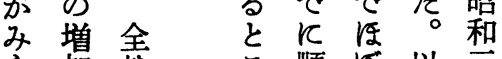

方加就と順注以三

産

業

構

造

の

変

化

と

中

等

教

育

岩

井

竜

也 
第 1 表

昭和29・34年に拈ける学歴別就業者総数

\begin{tabular}{|c|c|c|c|c|}
\hline \multirow{2}{*}{ 学 } & 実 & 数 & \multicolumn{2}{|c|}{$\%$} \\
\hline & 昭和 29 年 & 昭 和 34 年 & 昭和29年 & 昭和34年 \\
\hline 就 業 者 総 数 & $36,936,000$ & $40,579,600$ & 100 & 100 \\
\hline 初等数育卒就業者 & $30,176,700$ & $30,913.300$ & 81.7 & 76.1 \\
\hline 中等教育卒就業者 & $4,986,400$ & $7,367,100$ & 13.5 & 18.2 \\
\hline 高等教育卒就業者 & $1,763,200$ & $2,299,200$ & 4.8 & 5.7 \\
\hline
\end{tabular}

（聠場の学歴の現在と将来…文部省）

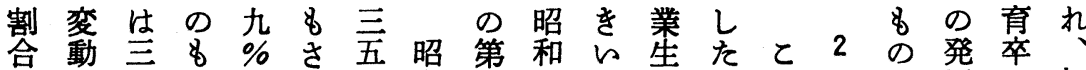

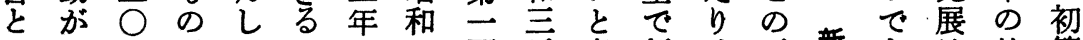

乙夕\%が北と云図五考新、五新的は就等 て 加製しとは八と年えし無年替あと業教 はれら造めな七年第言らく職間忽る。

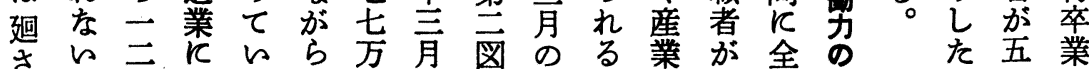

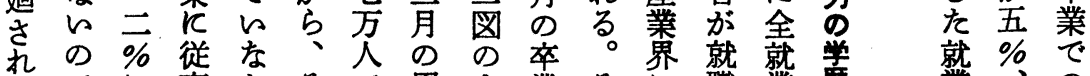

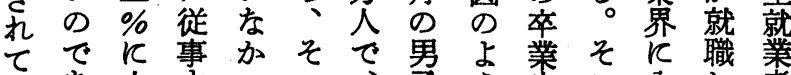
らあ大守っの、年ら生と入し者 るるきるた産約卒に先でるた 勘くと製業二業なつ文てと構 整りさい造別六生っ々部的成

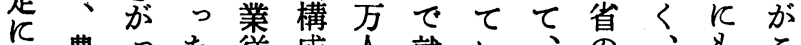

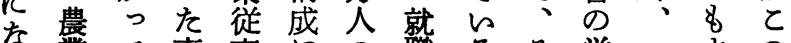
る業て事事にの職るそ学的よの 。従い情者は増し。の校わるよ 事ると古大加た 産基ゆ西

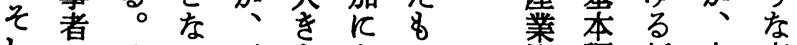

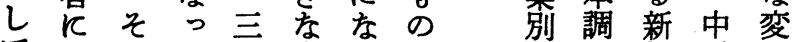
て相のて五変口は学查規学花 当他々年化て全歴学校を れ寻のるに方部構よ働亦

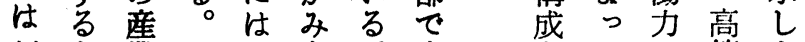

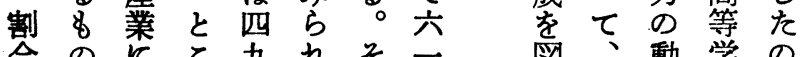
合の瓜机そ一図、動学の

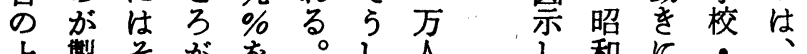

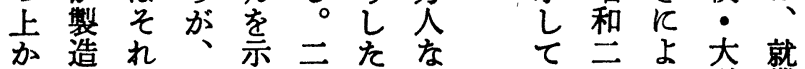

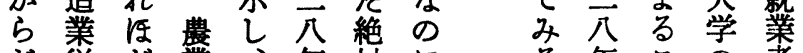
だ徉ど業、年対吕る年との者 け事大従約 $k$ の 六市新が で者を事半は增昭标転 な反者数三加和 次と大卒職

者 高 就

の 等 策

增 教 者

加育 と卒 議 教 の 務 育 就 教 程 篻 育 度 者修 の が桌 奌 $\frac{\text { 者 }}{\text { 者 }}$ 飞逆古 上六 口增 \%

七加 支しく 充索 b $\backsim<$ れるな c 果鏼中 机活等 た動教 
第 1 目 昭和28年 3 月中学・高校・大学卒業者の産業別学歴構成 一男子一

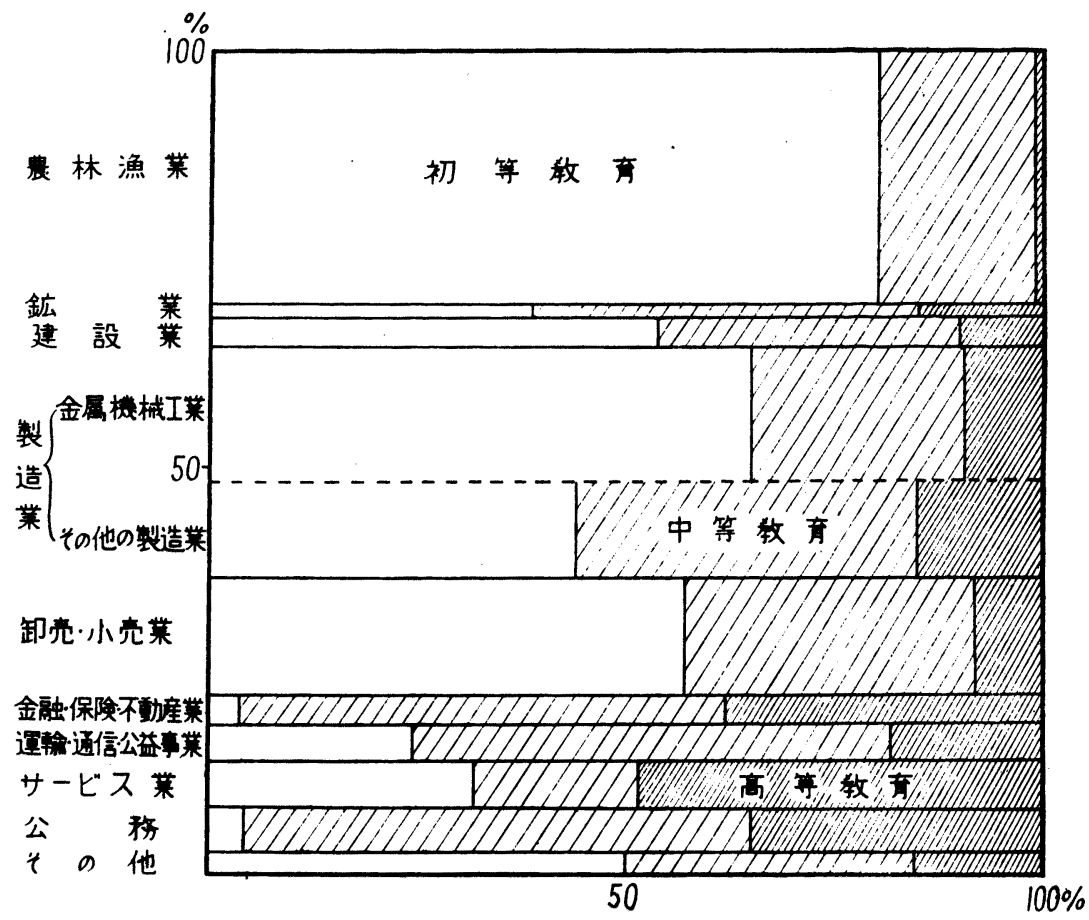

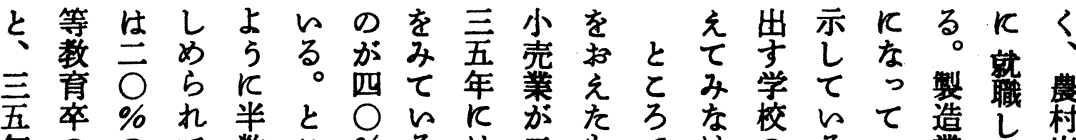

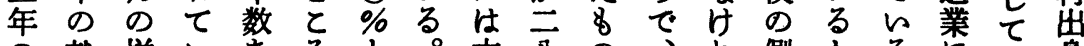

の就増にあると。六八の、れ側とるに的身

場菜加るまがまま七年が中ばですと約る者

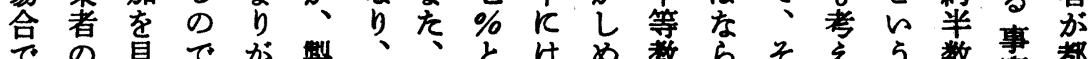

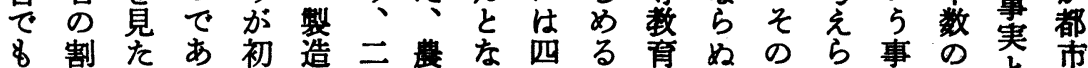

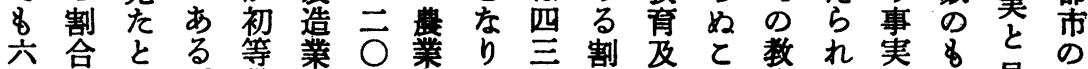

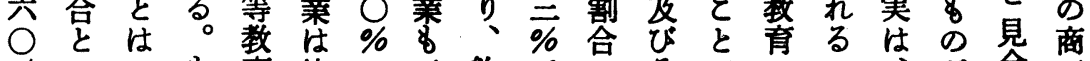

$\%$ r

を5 5 万卒然增 $\overrightarrow{\mathrm{O}}$ 等変机問で従口亲

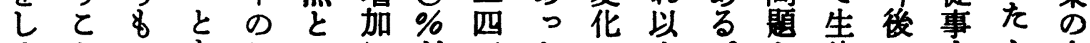

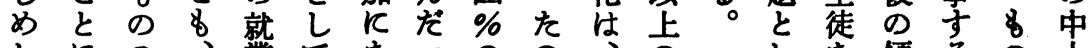

しKの、業てなっのの、年しを㑯るの小

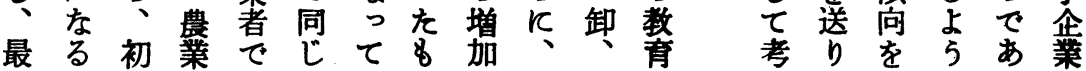


産業構造の变化と中等教育

第 2 目 昭和35年 3 月中学・高校・大学卒業者の掌別歴構成 一男于一

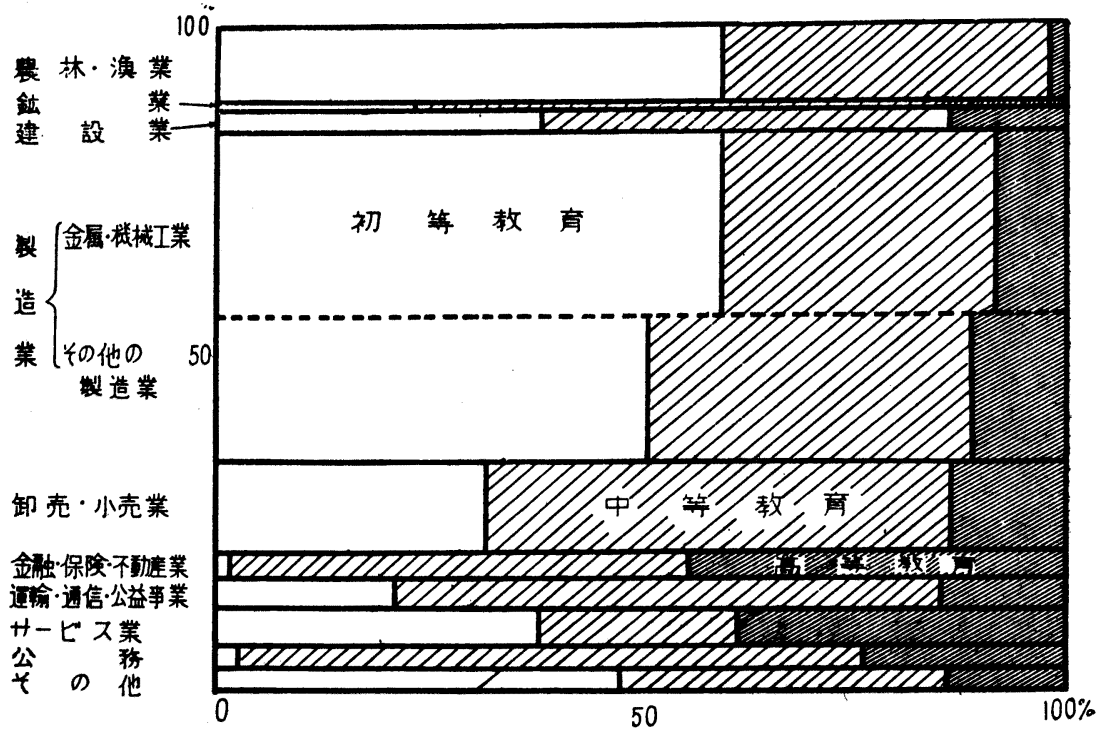
俥動て ち

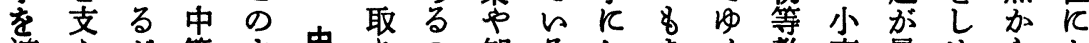
進允が等よ中

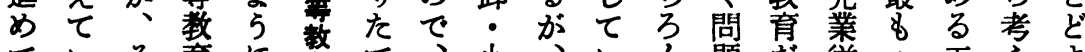

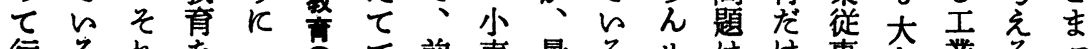
行る。扎をみのて前壳量るサはけ事を業るる

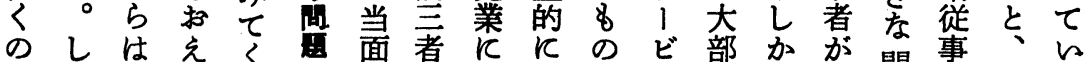

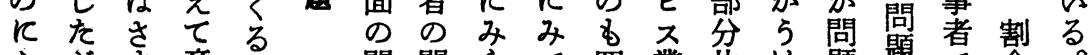

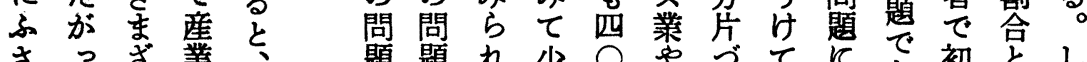

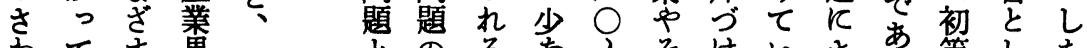

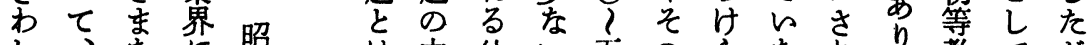

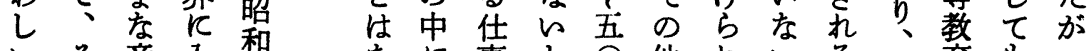

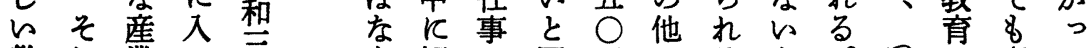

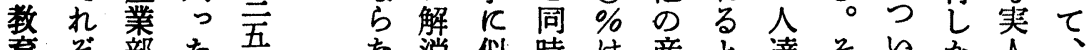

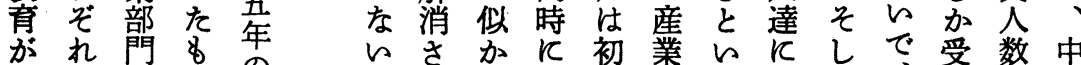

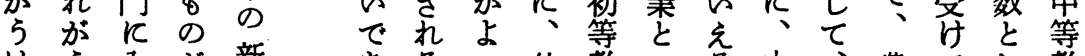
け5 万が新 あるっ仕教いる中農てし教 らけっ四想場た事育わの等そ業的て育

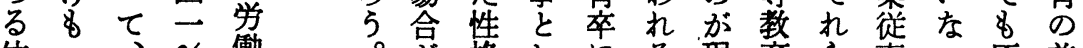

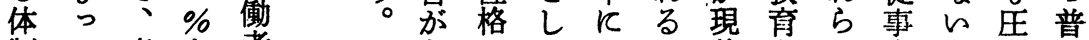
制て産を者 あのてと仕状をの者人倒及

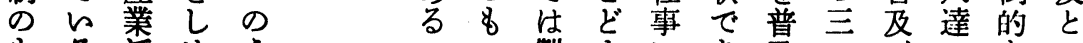

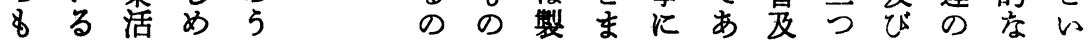


の男子-

(\%)

\begin{tabular}{|c|c|c|c|c|c|}
\hline \multicolumn{3}{|c|}{ ビス 業 } & \multirow{3}{*}{$\begin{array}{l}\text { 公 } \\
\text { 務 }\end{array}$} & \multirow{3}{*}{$\begin{array}{l}\text { そ } \\
\text { の } \\
\text { 他 }\end{array}$} & \multirow{3}{*}{ 計 } \\
\hline 映娛 & $\begin{array}{l}\text { そ } \\
\text { の }\end{array}$ & 計 & & & \\
\hline 画樂 & 他 & & & & \\
\hline 0.0 & 0.6 & 2.4 & 2.8 & 1.1 & 100 \\
\hline 14.5 & 11.2 & 15.8 & 10.8 & 9.4 & 23.8 \\
\hline
\end{tabular}

（文部統計速報）

りに界とちとなす

と入そやくろまのる 高 なっれ社的んるか場等

して ら 会 職そゔと合学

て 5 の

ゆけ問和課だな致

け \& 題け程けの高充

るだのる禁でか等義の

とさし位どはと学務ね

と机置であら校教ら

をてたづはをっに育ら

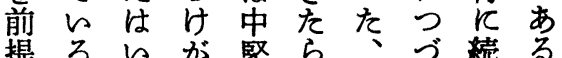

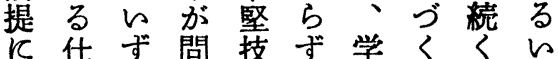

打事れ題術、校大少

らにに者高系学り教

て 即せさの 等 列 教 高育

問しょ机教学の育々内

題て現る㕕校見の国容

几、在場を教地前民突

し 産 の 合行育加提的構

七業高8なと教成

ら社等あ 5 独問し養に

な会学る \&自題てとあ

ら反校。の性に、した

よおのでをさいてっ

5 卒卒れ加何て

でて業るたがながの

あそ生と世方的方

るの离しるで内わ針

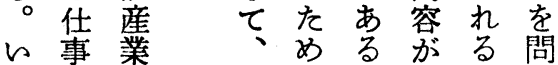

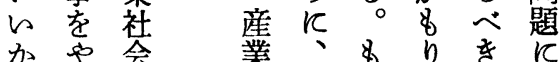

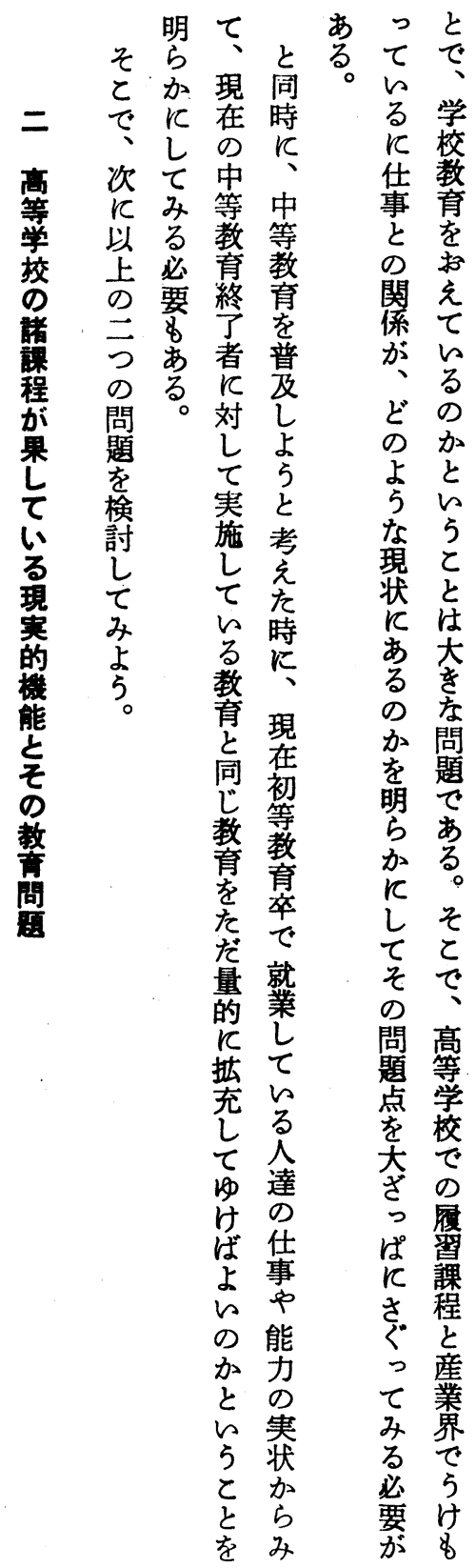

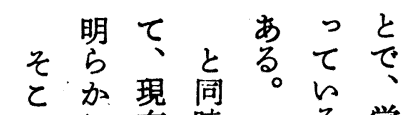

二でに在時 る

䯧次等

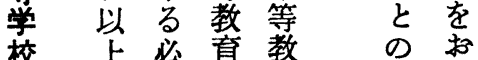

の の要終充 関 え

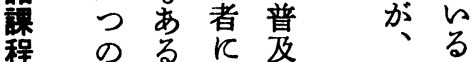

が 問。対しどの

果題しな の か

七 検 笑

い討施考度

るし元元琴と

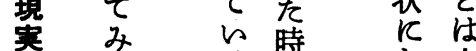

的占 る に教

龍現 の な

同在初を題

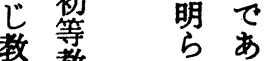

育咅等 る

た 卒 し そ

量就莱 の

に $て$ 問高

充点 学

し 人 を校

ゆ達艾の

けのっ履

ば仕 ぱ 翼

よ事䛲課

々や さ程

の能方京

とのて 業

々 奏 み 界

てか 必 5

を学尔要 
第 2 表

高等学校卒業生の就職状況 一昭和35年 3 月卒業

工 業 課 程

\begin{tabular}{|c|c|c|c|c|c|c|c|c|c|c|c|}
\hline 生 & 農 & 鉏 & 建 & 製 & 造 & 業 & 卸 & 金不 & 運公 & \multicolumn{2}{|c|}{ サ - } \\
\hline 緮 & $\begin{array}{l}\text { 林 } \\
\text { 唃 } \\
\text { 業 }\end{array}$ & 業 & $\begin{array}{l}\text { 設 } \\
\text { 業 }\end{array}$ & $\begin{array}{l}\text { 金工 } \\
\text { 属 } \\
\text { 機 } \\
\text { 械業 }\end{array}$ & $\begin{array}{l}\text { そ䡛 } \\
\text { の造 } \\
\text { 他造 } \\
\text { の業 }\end{array}$ & 計 & $\begin{array}{l}\text { 完 } \\
\text { 小 } \\
\text { 売 } \\
\text { 業 }\end{array}$ & 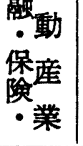 & $\begin{array}{l}\text { 輸益 } \\
\text { 通事 } \\
\text { 信莱 } \\
\text { - 業 }\end{array}$ & $\begin{array}{l}\text { 対家 } \\
\text { 個 } \\
\text { 人事 }\end{array}$ & $\begin{array}{l}\text { 対修 } \\
\text { 事 } \\
\text { 慗 } \\
\text { 所理 }\end{array}$ \\
\hline 75,633 & 0.6 & 1.1 & 13.0 & 44.6 & 23.1 & 67.6 & 4.1 & 0.2 & 7.1 & 0.5 & 1.3 \\
\hline 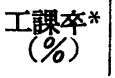 & 1.2 & 33.7 & 69.3 & 47.7 & 28.5 & 38.8 & 5.1 & 1.2 & 23.8 & 9.2 & 28.9 \\
\hline
\end{tabular}

（* 各産業ことに高卒就職者を100とした場合の工桠課程卒の割合）

の

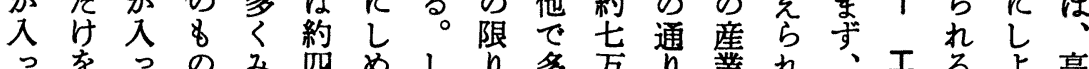
て考て だら $\bigcirc$ る か をえいけれ\%割しおの市のあの鉣在等と学

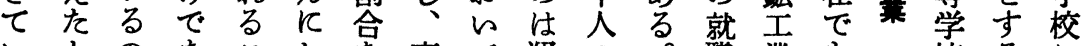
らとのなとしを高て運の職業\& 校るて

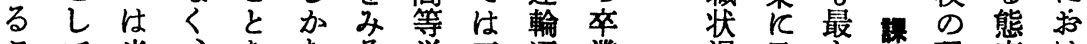
てて当、をなる学工通業況見8 現度け

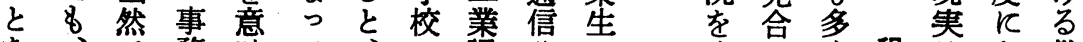
を、で務味て、公課公の 文 5 く程的众教 意工あ部しい建全程益六都課の 機け育 味業る門てな設課は事八省筀就能ての

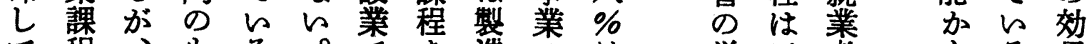

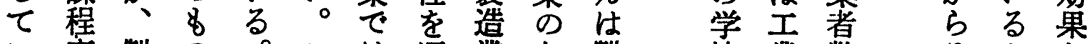

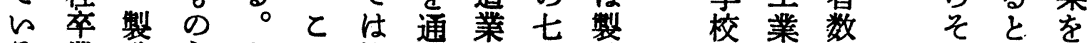

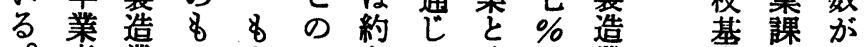
。者業 ら方と七て建ぐ業 ととのる る $\bigcirc$ そ設 ら れ同仕のんは\%業ら従

はじ事で製 製でぞにの事 教よのあ造造あれ従 \&

育 5 構る業業たの事の

とな成加従従る産すで一をを字察とす

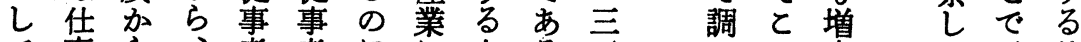

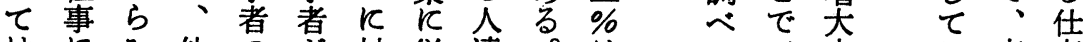
はにみ他の方対従達。は卒事 問他たの中他し事をし建をみ業る

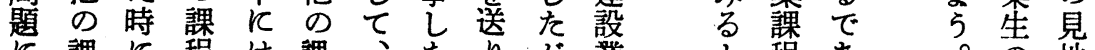
課に程は課、た方が業程あ

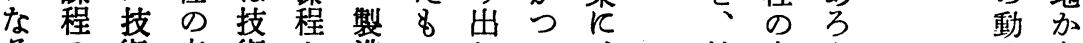
るの術卒術汃造の して、第卒ら 策 こ 部業部ら 業の て そ 普と 


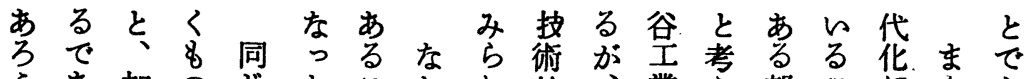

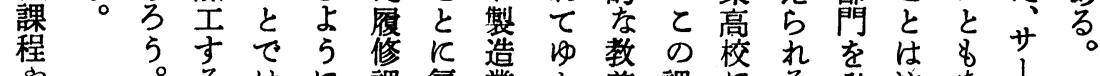

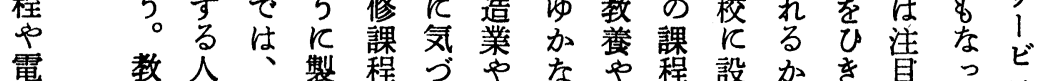

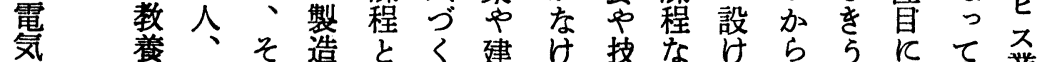

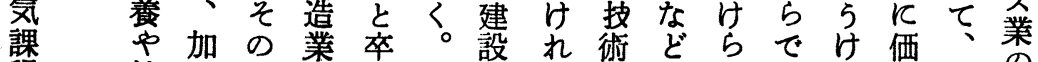
程技工必番国業ばはでれあて年の で能さ要従後立になかはてる機る造中

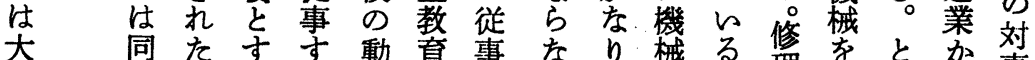

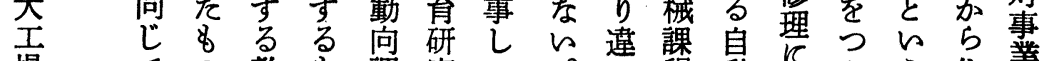

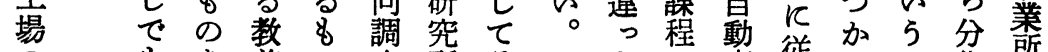
の क を意の查所る 生检市と古卒

の、巷名業年事

働方程て事仕方尔

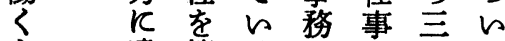

8 違管る 部の言て

の 々理。彨内年多

が がしと $k$ 容 $飞 、$

多 あた同働穵古

々 るりじくにけの

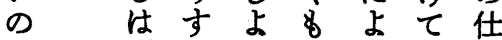

飞ずる5のる関事

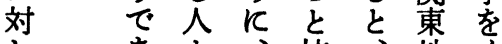

七 るとで势術次方わ

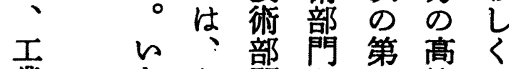

業华必要膶あ言等し

学 構安安的极立

課造香、は牥てて

程 がる生現第つ

で違教産場四いる

は 5 養守とのてと

生々 $々 る$ 通事同

産考技务わ号例じ

管公能の机で研よ

理てがをるあ究5

部文違考部るとな

門よっ之䦎。し問

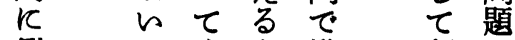

働でく人働行茄

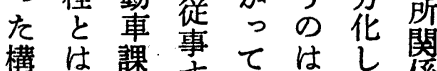

造異程亭仕製た係

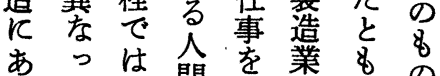

るた告間枽菜考方

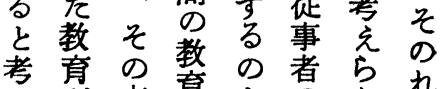

充卒充文帛机

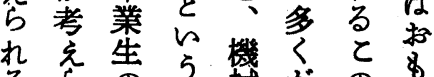

る

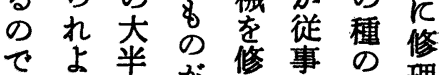

5架考理し産理

そと戛考宗告業業

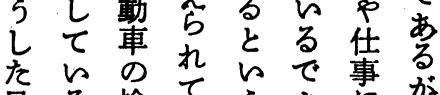

省る

地同查台任方 5 䄪

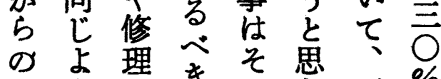

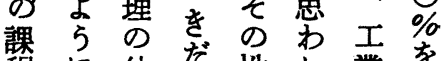

程に仕だ性杂業を

の電事吕格る課

教気に艺を它程 と

育機従あか定のて

の器事る な卒る

成修七東異産生産

反理に京飞工社業

工 る る 都 し 程 活 組

夫生の.のての躍織

が産で世に中しの

試多あ田るのて近 
绻了表

出身課程別にみた媻造業従事者の仕事

\begin{tabular}{|c|c|c|c|c|c|c|c|c|c|c|}
\hline \multirow{2}{*}{ 課 } & \multirow{2}{*}{ 程 } & \multirow{2}{*}{ 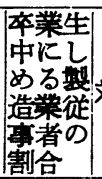 } & \multirow{2}{*}{ 対象数 } & \multicolumn{4}{|c|}{ 職埸の從業員規模 } & \multirow{2}{*}{\multicolumn{3}{|c|}{ 従事している仕事の分野 }} \\
\hline & & & & $1 \sim$ & $\begin{array}{l}100 \sim \\
199 人\end{array}$ & $200 \sim$ & 500 人上 & & & \\
\hline 機 & 械 & $\%$ & $\begin{array}{r}\text { N } \\
1.430\end{array}$ & $\%$ & $\%$ & $\%$ & $\begin{array}{l}\% \\
52\end{array}$ & 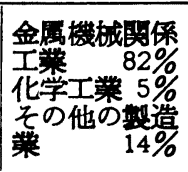 & $\left\{\begin{array}{l}\text { 生産管理 } \\
\text { 現埸作業 } \\
\text { その 他 }\end{array}\right.$ & $\begin{array}{r}59 \% \\
37 \% \\
7 \%\end{array}$ \\
\hline 管 & 気 & 53 & 405 & 18 & 7 & 21 & 55 & 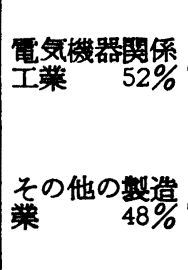 & 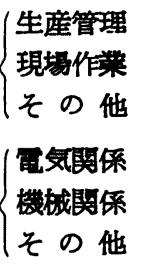 & $\begin{array}{r}81 \% \\
13 \% \\
6 \% \\
57 \% \\
25 \% \\
17 \%\end{array}$ \\
\hline 工業化学 & & 67 & 374 & 22 & 12 & 19 & 48 & 化 学 工 & $\left\{\begin{array}{l}\text { 生産管理 } \\
\text { 現堵作業 } \\
\text { 機械装置 } \\
\text { の運転 }\end{array}\right.$ & $\begin{array}{l}53 \% \\
44 \% \\
29 \%\end{array}$ \\
\hline
\end{tabular}

（国研紀要 第26集）

しる課目中と程 れ教考て傾で来せン棣従く い程 方寺施し 設 な

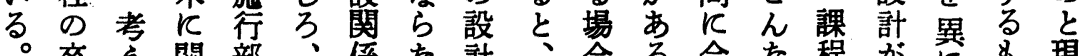

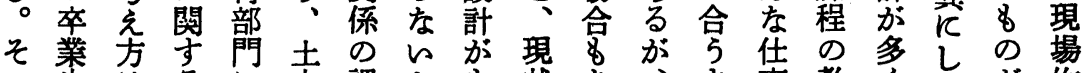

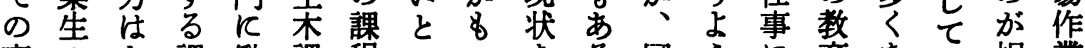

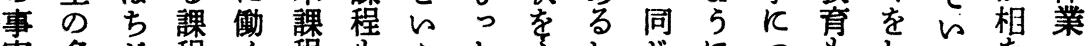

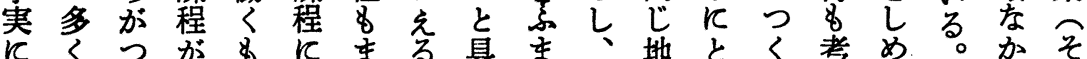

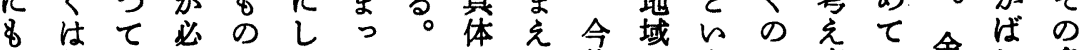

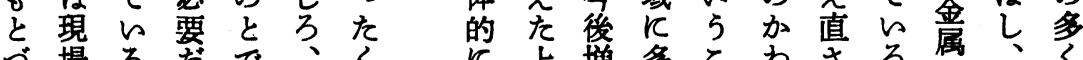

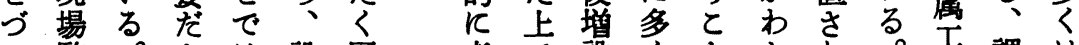

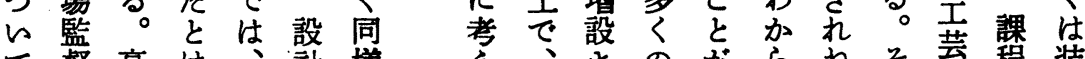

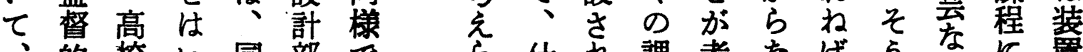
、的校に同部で占仕訲考なば

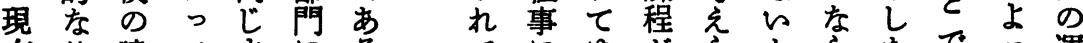

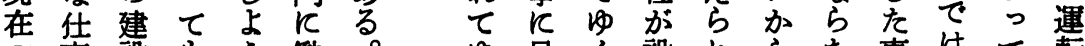
の事設8 5 働。見く設れらな事は転

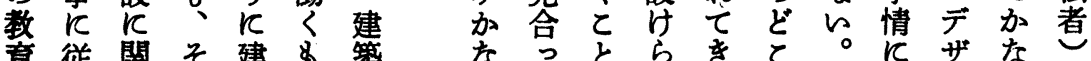

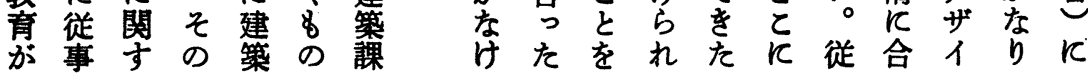


第 4 表

建設・土木課程出身者の仕事

建 築 課 程

(\%)

\begin{tabular}{|c|c|c|c|c|c|}
\hline 産業 & 建 設 関 係 & 業 & \multicolumn{2}{|l|}{ 建設関係業以外 } & \multirow{2}{*}{ 合 } \\
\hline & 設監設見 現 事 & そ & 建設に関係ある仕事 & 建仕 & \\
\hline $\begin{array}{l}\text { 従 } \\
\text { 業 } \\
\text { 者 } \\
\text { 総 } \\
\text { 数 }\end{array}$ & 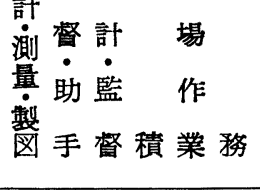 & $\begin{array}{l}\text { の計 } \\
\text { 他 }\end{array}$ & 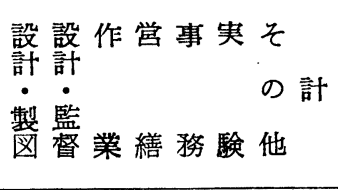 & $\begin{array}{l}\text { 設事 } \\
\text { k } \\
\text { 関 } \\
\text { 采 } \\
\text { な } \\
\text { い }\end{array}$ & 計 \\
\hline 소 & $\begin{array}{llllll}7 & 20 & 8 & 1 & 3 & 1\end{array}$ & 341 & $\begin{array}{llllllll}8 & 5 & 2 & 3 & 1 & 1 & 3 & 22\end{array}$ & 37 & 100 \\
\hline
\end{tabular}

（国研紀要 第26集）

土木課 程

$(\%)$

\begin{tabular}{|c|c|c|c|c|c|c|c|c|c|c|c|}
\hline & & 土 & 木 & 目 & & 系 & 業 & 枒 & & \multirow{2}{*}{$\begin{array}{l}\text { 土業 } \\
\text { 雅 } \\
\text { 閣 } \\
\text { 係 } \\
\text { な } \\
\text { W }\end{array}$} & \multirow{2}{*}{$\begin{array}{c}\text { 合 } \\
\text { 計 }\end{array}$} \\
\hline $\begin{array}{l}\text { 従 } \\
\text { 業 } \\
\text { 者 } \\
\text { 総 } \\
\text { 数 }\end{array}$ & $\begin{array}{l}\text { 現 } \\
\text { 場 } \\
\text { 監 } \\
\text { 督 }\end{array}$ & $\begin{array}{l}\text { 測 } \\
\text { 量 }\end{array}$ & $\begin{array}{l}\text { 設 } \\
\text { 謰 } \\
\text { 製 } \\
\text { 図 }\end{array}$ & $\begin{array}{l}\text { 調 } \\
\text { 查 } \\
\text { 研 } \\
\text { 究 }\end{array}$ & $\begin{array}{l}\text { 工 } \\
\text { 事 } \\
\text { 事 } \\
\text { 務 }\end{array}$ & $\begin{array}{l}\text { 業 } \\
\text { 務 }\end{array}$ & $\begin{array}{l}\text { 作 } \\
\text { 業 }\end{array}$ & $\begin{array}{l}\text { そ } \\
\text { の } \\
\text { 他 }\end{array}$ & 計 & & \\
\hline 228 & 15 & 17 & 13 & 2 & 3 & 43 & 1 & 3 & 86 & 15 & 100 \\
\hline
\end{tabular}

(国研紀要 第26集)

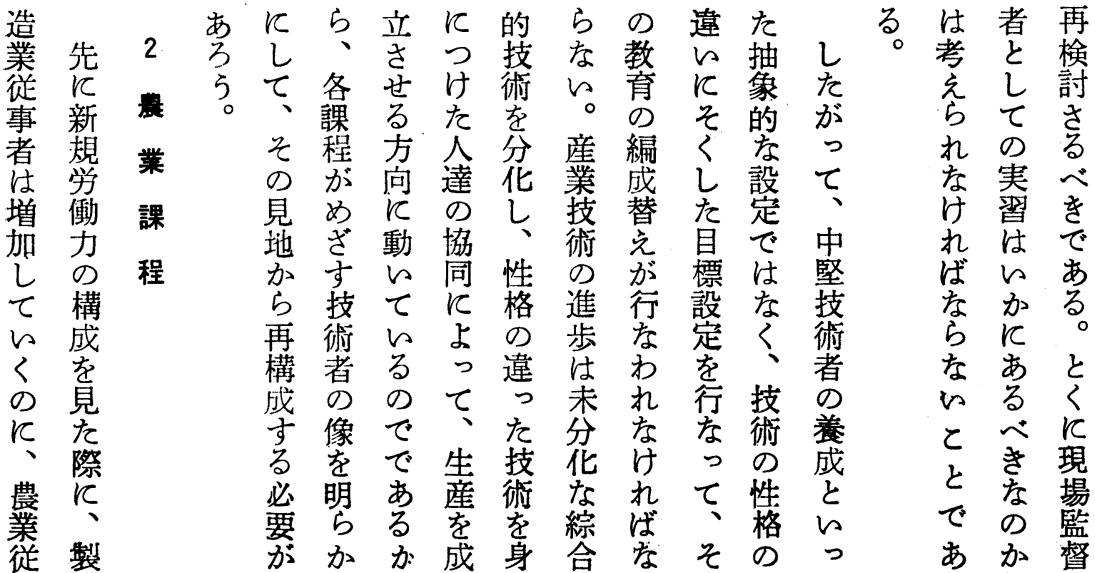




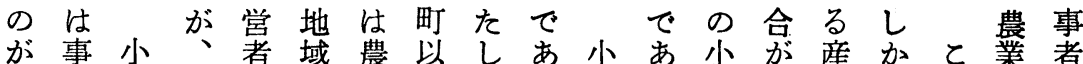
ら情課農ののの業上てる課る課多業しれ課は

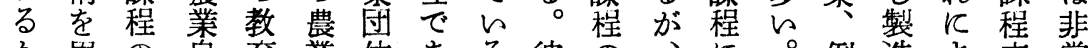
か異の自育業体ある彼の、年例造よ卒常 とに農営と指、り。ら農と\&農え莱る 業に らし業者い導あ、しの業れれっ業薄従と、者少 与七課を と程ね点と的し五程小卞桯料者㷊産く そるはらに文は五と\%の課る全品が業業な れ。以っお い地町こは出程 ど体言従別っ はと上ていえ域以で農身のくと業五業就て 非れの 効てる団上注業者農あしと都職い

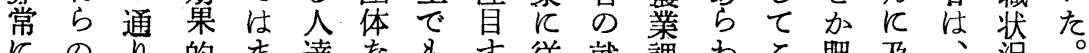

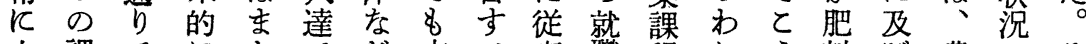
少課で程 あ 行 ま

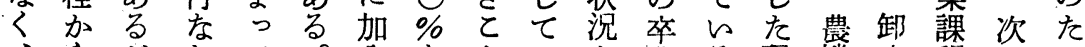
一ら古わて。人をと的を業る現機小程のめ

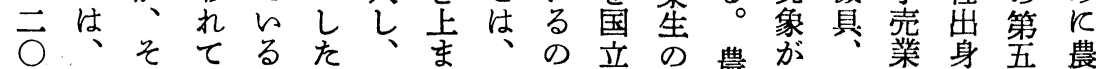

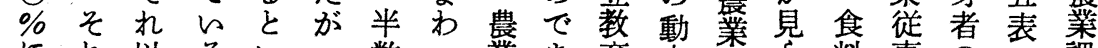

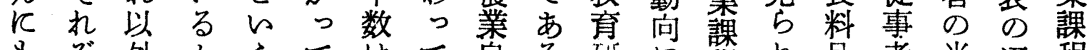

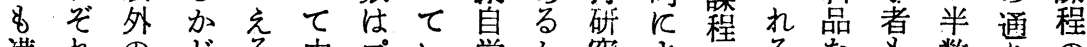

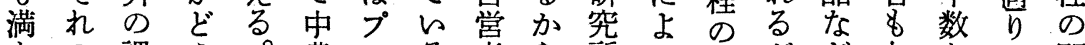
たの課 5 農品る者ら所るる出がど七学で問

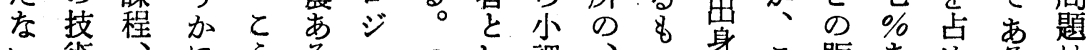

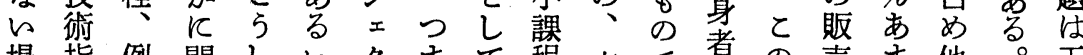
場指例問しいクをて 程 卒で者の売ま他。立 合導え題た は ト り の

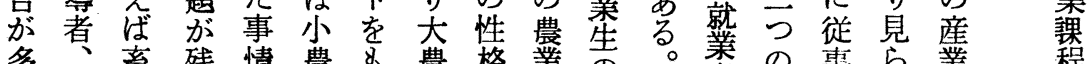
多、畜 残 情 農 \& 農格業告。羓の事ら業程

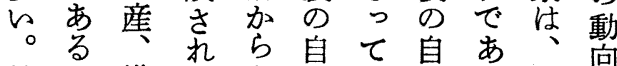
特織 る。考営農賞る。農調 斜技農 る の 研索々自查 陽術業尔究究ので九学な 業活農 課機方あ○者 で用産 程関づる の と るき農はてそり機る 織るな業ないししは関と 維任 ど課っるて文次 農事の程て人彼経しの 業に課 のい達ら営て第 な従程 現なでの地の六 ぞ事は 在 は にすをのがい分積割の 至るれ教、わの艺如 っ と䏍自ば三一果く

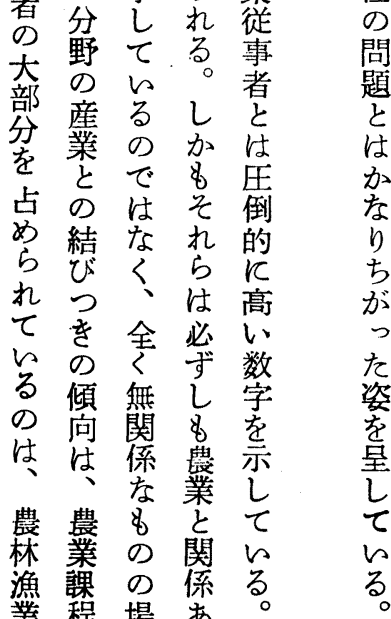


卒業生の就職状況 一昭和35年 3 月卒業の男子一

$(\%)$

\begin{tabular}{|c|c|c|c|c|c|c|c|c|c|c|c|}
\hline 業 & 㶯 & 金不 & 荲公 & & サ - & ヒ́ & 营 & & 公 & そ & \\
\hline 計 & $\begin{array}{l}\text { 小 } \\
\text { 壳 } \\
\text { 㱉 }\end{array}$ & 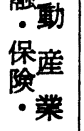 & • 通益益 & $\begin{array}{l}\text { 刘傢 } \\
\text { 個 } \\
\text { 人栤 }\end{array}$ & $\begin{array}{l}\text { 対修 } \\
\text { 惠 } \\
\text { 菻 } \\
\text { 所理 }\end{array}$ & $\begin{array}{c}\text { 映坮 } \\
\text { 画楽 }\end{array}$ & $\begin{array}{l}\text { そ } \\
\text { の } \\
\text { 他 }\end{array}$ & 計 & 務 & $\begin{array}{l}の \\
\text { 他 }\end{array}$ & 計 \\
\hline 24.7 & 7.3 & 0.3 & 3.1 & 0.5 & 0.6 & 0.1 & 1.2 & 2.5 & 7.1 & 2.0 & 100 \\
\hline 9.0 & 5.9 & 1.2 & 6.6 & 6.0 & 8.0 & 5.8 & 15.4 & 9.6 & 17.1 & 11.4 & 15.2 \\
\hline
\end{tabular}

合の農業棵程卒の割合)

（文部統計速報）

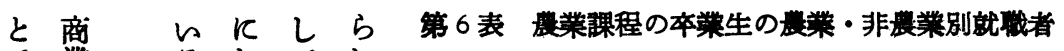

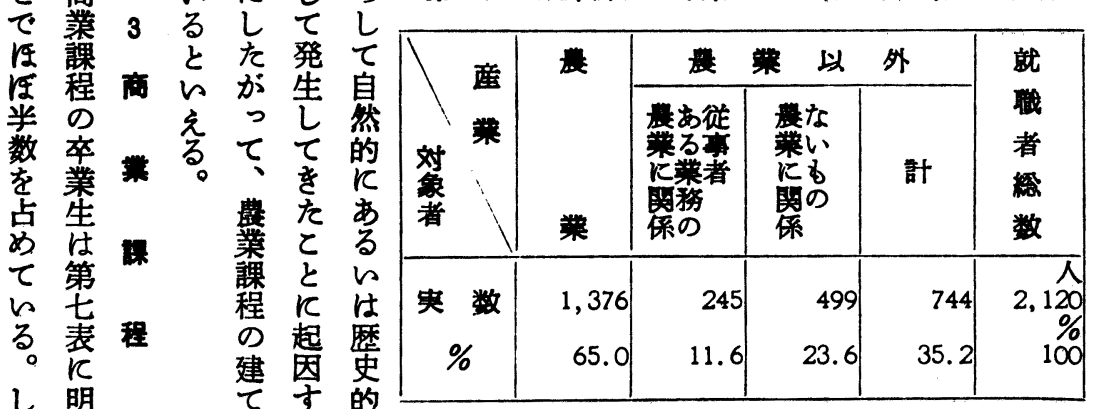

等琞

$\tau$ 的

原

が か

3 な

$\tau$ 如

商

䈻

係売

の 小

澲壱

灾

見 金

合 融

$\tau$ 険

的不

る 動

旁礏

直る 社

ᄂ के 会

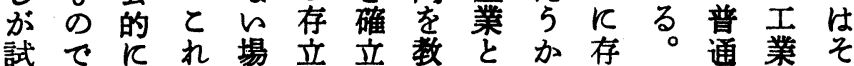

なのを間産えめいるのて

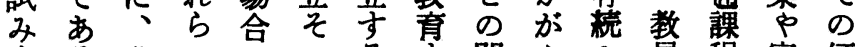

らろ農のさのる年閶えさ筫程官傾

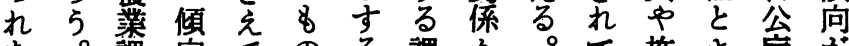

な。課向でのる課か。て施さ庁か

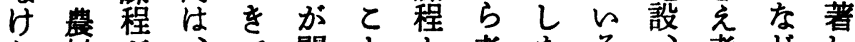

れ村加、問とと考たる、考とし

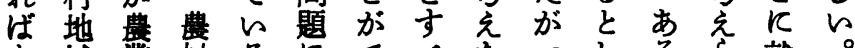

な域業树るにでっしる就。

らの地と。さををとてかいれ職そ

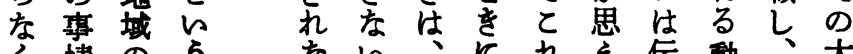

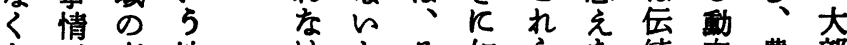

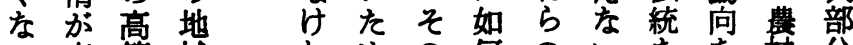

変等域れめの何の的をを符分

て貌学条ばにねな課場ど示に性

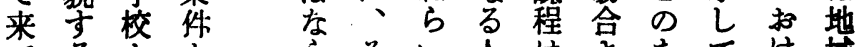

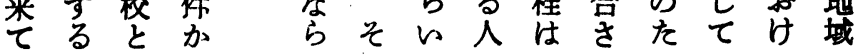


歹 $k$ 拡充て第5表

高等学校

一以 4 よ る.充分的

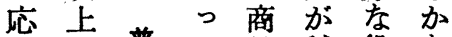

組晋て品試役な

ま職知 \% 割り

れ業通そ識ら製

て課速ののれ果品

意程要学なすに

$\tau 反$ 課 求習けと関

的関的灾机守

るし 答はばがる

の元程管間なて技

で見な反らを術

あ将合店的

る来机わ的な

加范な。知

らの皇単識

農 業 課 程

\begin{tabular}{|c|c|c|c|c|c|}
\hline 産 & 農 & 鉱 & 建 & & 造 \\
\hline 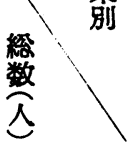 & $\begin{array}{l}\text { 林 } \\
\dot{\text { 涌 }} \\
\text { 業 }\end{array}$ & 業 & $\begin{array}{l}\text { 設 } \\
\text { 業 }\end{array}$ & $\begin{array}{l}\text { 金工 } \\
\text { 愿 } \\
\text { 機 } \\
\text { 械業 }\end{array}$ & $\begin{array}{l}\text { そ製 } \\
\text { の造 } \\
\text { 倬業 }\end{array}$ \\
\hline 48,026 & 50.0 & 0.3 & 2.6 & 10.4 & 14.3 \\
\hline $\begin{array}{l}\text { 農課卒* } \\
(\%)\end{array}$ & 71.0 & 6.4 & 8.9 & 7.1 & 11.3 \\
\hline
\end{tabular}

（*各産業ことに高卒就裁者を100とした域

てでとなる

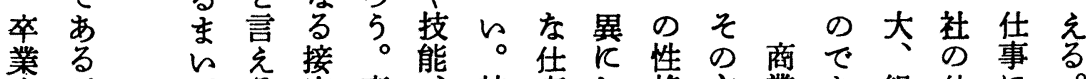

生 が

动 職

向 業

K 課

照 程

ら

予来

想 卒

と業

現 後

実 $\mathrm{C}$

の 従

ず事

れ

孛

茌

処 を

置 前

专 提

吕兄

あそ

るの

袮

は龍

漠 内

然容

で容商

あ術やる

万以製

5 上嵒

乙何高産係

灰物度過

加加华程

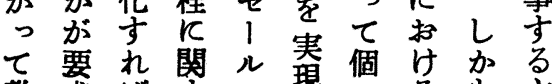

教求壮守不琵名的主

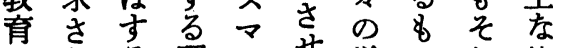

の机る理义芆学のれ任

ねて疻解性名校で占事

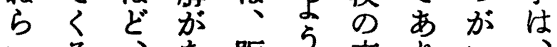

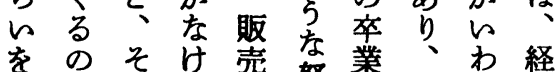

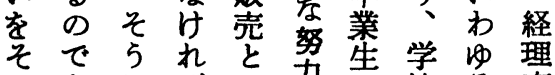

とあしば方兮の校る事

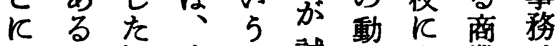

打加観生仕試向上業

的点産事み $反>$ 一

た $\kappa c k$ 即 $\tau$ 金般

全従立消従れし吕融事

体来咅費事なて業務

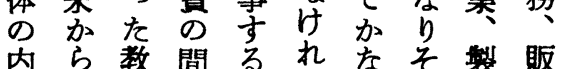

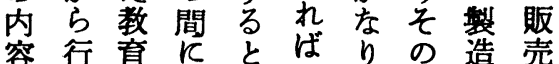

のな内立はな具事業な

構っ容っ言る体情など

成
あ 組 仕

万織事従製

5 ので事造

垫 あ 紊

充るて 従

点的事

と㤎る者

注。が

な首前揱

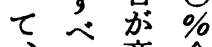

を商 余

商 と業 り

業 简

課 菜係

程あのれ

出 万仕る

身 5 事 が

者。でそ

の工新業半

新業る 数

的闇封

進係対 事

出の務

分企强

野業と至

とのれ営

言規は業

充 模 生 関

るの産係

\& 增会 の 


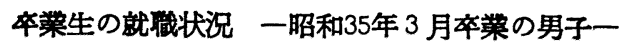

(\%)

\begin{tabular}{|c|c|c|c|c|c|c|c|c|c|c|c|}
\hline 業 & 卸 & 金不 & 運公 & & サ - & ビ & 又 業 & & 公 & そ & \\
\hline 計 & $\begin{array}{l}\text { 京 } \\
\text { 売 } \\
\text { 業 }\end{array}$ & 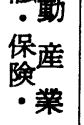 & $\begin{array}{l}\text { 通益 } \\
\text { 信 } \\
\text { - 業 }\end{array}$ & $\begin{array}{l}\text { 対家 } \\
\text { 個 } \\
\text { 人事 }\end{array}$ & $\begin{array}{l}\text { 対修 } \\
\text { 事 } \\
\text { 燥 } \\
\text { 所理 }\end{array}$ & $\begin{array}{l}\text { 映娱 } \\
\text { 画楽 }\end{array}$ & $\begin{array}{l}\text { そ } \\
\text { の } \\
\text { 他 }\end{array}$ & 計 & 務 & $\begin{array}{l}\text { の } \\
\text { 他 }\end{array}$ & 計 \\
\hline 31.5 & 38.7 & 9.1 & 6.5 & 1.5 & 1. 1 & 0.2 & 1.0 & 3.8 & 4.1 & 2.7 & 100 \\
\hline 19.2 & 52.5 & 55.4 & 23.1 & 31.2 & 26.9 & 31.0 & 21.6 & 26.9 & 16.6 & 25.7 & 25.4 \\
\hline
\end{tabular}

卒業生の就職状況 一昭和35年 3 月卒業の男子一

$(\%)$

\begin{tabular}{|c|c|c|c|c|c|c|c|c|c|c|c|}
\hline 業 & \multirow{2}{*}{ 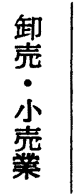 } & \multirow{2}{*}{$\mid \begin{array}{c}\text { 金不 } \\
\text { 融動 } \\
\text { 保産 } \\
\text { 险業 }\end{array}$} & \multirow{2}{*}{$\begin{array}{l}\text { 運公 } \\
\text { 益 } \\
\text { 通事 } \\
\text { 售業 }\end{array}$} & \multicolumn{5}{|c|}{ サービス業 } & \multirow{2}{*}{ 公 } & \multirow{2}{*}{$\begin{array}{l}\text { そ } \\
\text { の } \\
\text { 他 }\end{array}$} & \multirow{2}{*}{$\begin{array}{l}\text { 合 } \\
\text { 計 }\end{array}$} \\
\hline 計 & & & & $\begin{array}{l}\text { 対家 } \\
\text { 個 } \\
\text { 人事 }\end{array}$ & $\begin{array}{l}\text { 対修 } \\
\text { 亳 } \\
\text { 寒理 }\end{array}$ & $\begin{array}{c}\text { 映加 } \\
\text { 画楽 }\end{array}$ & $\begin{array}{l}\text { そ } \\
\text { の } \\
\text { 他 }\end{array}$ & 計 & & & \\
\hline 37.8 & 19.4 & 5.1 & 9.1 & 1.9 & 1.1 & 0.2 & 1.7 & 4.9 & 9.9 & 4.0 & 100 \\
\hline 31.4 & 35.5 & 41.9 & 44.0 & 52.6 & 34.8 & 47.8 & 50.5 & 46.4 & 54.6 & 52.6 & 34.4 \\
\hline
\end{tabular}

合の普通課程卒の割合)

（文部統計速報）

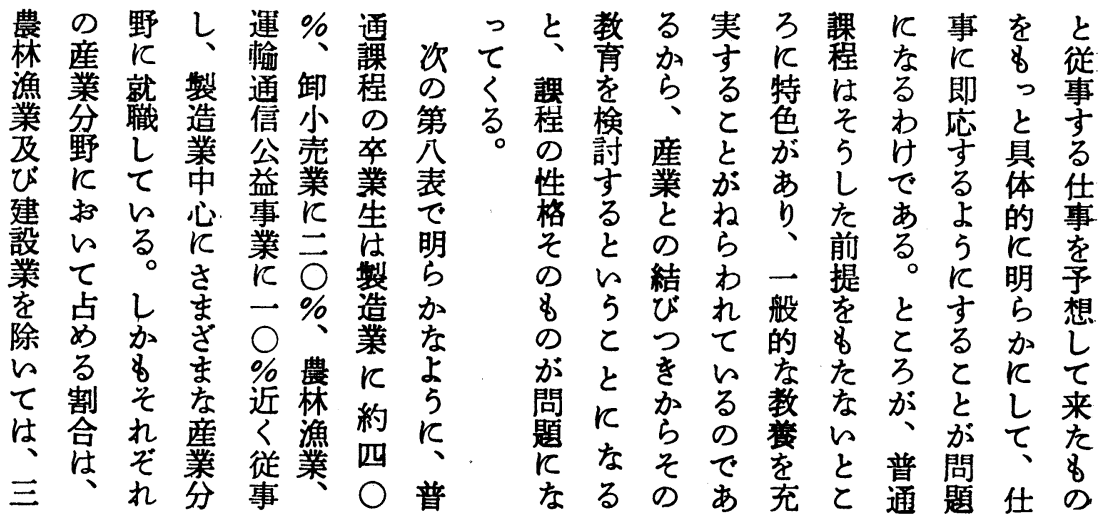


るにりては員が がこはまい、とっ 、 5 変とるいなて こしりま点わばそ のたなっがゆれの 二傾的普るる七 $\bigcirc$ 向。傾通総加 $\bigcirc$ 年を向課合工 $\%$ 間安程制技余 Кつ示のの術り 約普守問榚者 五通題相作 $\%$ 課要でを普業 の程 万発通者 減の \&揮課で を卒な。し程あ み業的名加り た生でちい占生 反方尔る多産 す高学々く管 き校的言出理 势卒加学完て分 昭の、校るい門 和全多 $K$ る

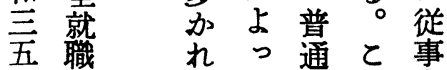
年者少て課の方 でに加そ程よる \&し 打の 和地的は 五るさ域 5 卒残 $\%$ 割高の-業り

の合さ歴つ生の 多委史のの号 第店的課動 $\overline{\mathrm{O}}$ を一任、程向 \%

乙 0 事社で近

め表化会あらく

ての的りすで

打占条なる

り 5 人件がをる

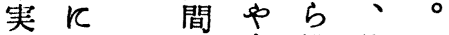

数年を産総普 し

の々送業合通た

上さ り事制課驾

で出情 の程引

はっしK役 $っ て$

逆 $\tau$ 割現的

反的㹸実わ

增元 るて果的ゆ

加は傾加た機る

の々向なし能立
第 7 表

高等学校

商 業 課 程

\begin{tabular}{|c|c|c|c|c|c|}
\hline 轐 & 農 & 鉣 & 建 & & 造 \\
\hline $\begin{array}{l}\text { 総 } \\
\text { 数 } \\
\text { 人 }\end{array}$ & $\begin{array}{l}\text { 林 } \\
\text { 漁 } \\
\text { 業 }\end{array}$ & 業 & $\begin{array}{l}\text { 設 } \\
\text { 業 }\end{array}$ & 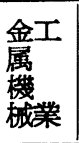 & $\begin{array}{l}\text { そ製 } \\
\text { 他造 } \\
\text { の業 }\end{array}$ \\
\hline 80,732 & 1.6 & 0.3 & 1.5 & 13.6 & 18.0 \\
\hline $\begin{array}{l}\text { 商課卒* } \\
(\%)\end{array}$ & 3.8 & 9.7 & 8.7 & 15.4 & 23. \\
\hline
\end{tabular}

（* 産業ことと高卒就業者を100とした場合

第 8 表

高等学校 普通 锞 程

\begin{tabular}{|c|c|c|c|c|c|}
\hline 産 & 農 & 鉱 & 建 & & 造 \\
\hline હ & $\begin{array}{l}\text { 林 } \\
\text { 漁 } \\
\text { 業 }\end{array}$ & 業 & $\begin{array}{l}\text { 設 } \\
\text { 業 }\end{array}$ & $\begin{array}{l}\text { 金工 } \\
\text { 属 } \\
\text { 機 } \\
\text { 械業 }\end{array}$ & $\begin{array}{l}\text { 资製 } \\
\text { 他造 } \\
\text { 澲 }\end{array}$ \\
\hline 109,861 & 7.3 & 1.2 & 1.7 & 19.0 & 18.7 \\
\hline $\begin{array}{c}\text { 普通卒* } \\
(\%)\end{array}$ & 22.9 & 49.8 & 12.9 & 29.4 & 33.6 \\
\hline
\end{tabular}

（“各産業ごとに高卒就職者を100とした䩙

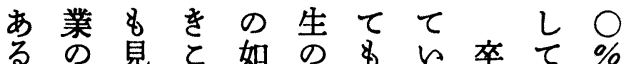
。現台々動同る業的加 工場れ在飞向様事生る 業分る、調飞情唯。五 課門と現っ查 5 はを

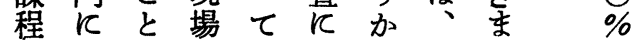
の従で作いよが従ざ 機事あ業るるえ事主的

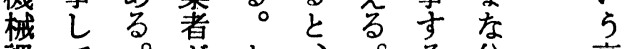
課て。方た高分高 程々四だ次国仕野的 るれ○注の研秝飞割 ど\&は\%自第のか就合

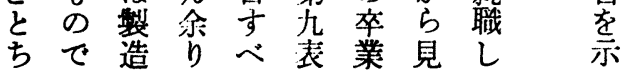




\begin{tabular}{|c|c|c|c|c|c|c|c|c|c|c|c|}
\hline & \multicolumn{5}{|c|}{ 数 } & \multicolumn{6}{|c|}{$\%$} \\
\hline & 業 & & 現 & そ & 不 & 事 & 営 & 現 & そ & 不 & \\
\hline 肘 & $\begin{array}{l}\pi \\
の\end{array}$ & 計 & $\begin{array}{l}\text { 場 } \\
\text { 作 }\end{array}$ & の & & & & $\begin{array}{l}\text { 場 } \\
\text { 作 }\end{array}$ & の & & 唁 \\
\hline 売 & 他 & & 業 & 他 & 明 & 枒 & 夆 & 業 & 他 & 明 & \\
\hline 78 & 179 & 672 & 1,096 & 217 & 120 & 21 & 25 & 41 & 8 & 5 & 100 \\
\hline
\end{tabular}

課程の就識者数の增大一男子一

\begin{tabular}{|r|c|r|r|r|r|r|r|}
\hline \multicolumn{1}{c|}{28} & \multicolumn{1}{c|}{30} & \multicolumn{1}{c|}{31} & \multicolumn{1}{c|}{32} & 33 & \multicolumn{1}{c|}{34} & \multicolumn{1}{c|}{35} \\
\hline 194,729 & 217,701 & 224,679 & 249,162 & 264,239 & 267,825 & 288,040 & 318.898 \\
\hline 77,201 & 80,561 & 81,418 & 88,657 & 97,140 & 95,253 & 99,139 & 109,861 \\
\hline 39.7 & 37.0 & 36.3 & 35.6 & 36.8 & 35.7 & 34.4 & 34.5 \\
\hline
\end{tabular}

\section{（学校基本調査・産業教育調查）}

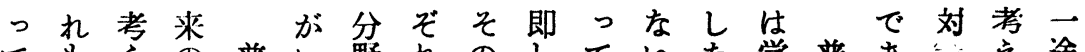
て ら選や職通\&宁の方て、と教問通る。をたを る択々業課見\&産がそ将々盖的課。構と辿 の科の生程逃の業 で目試活唯で人そし従わ積養でなとて

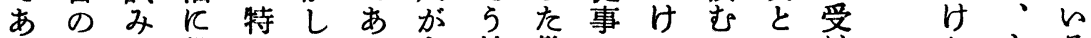

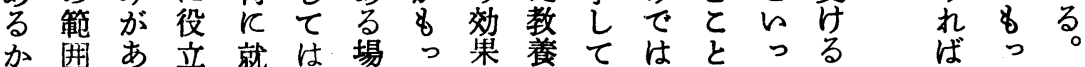

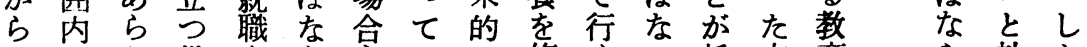
、でわ教者ら多らで修くい将方育等た

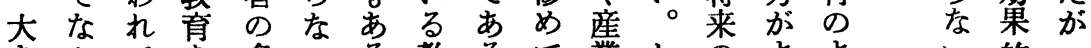
きんてを多いる教るてて業しするよる。的っ

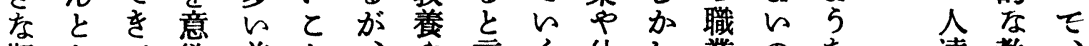

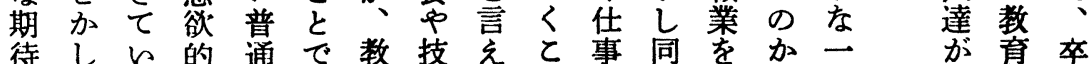

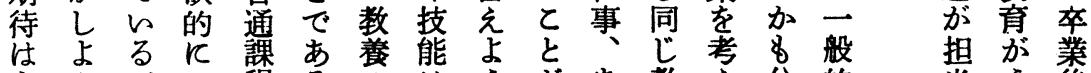

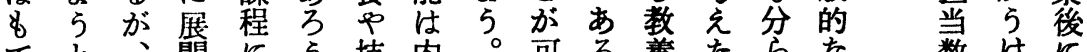

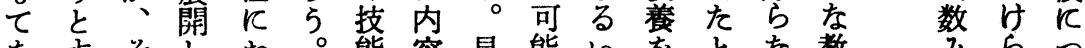

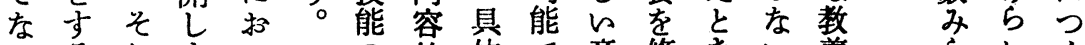

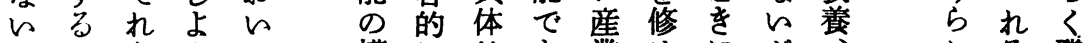

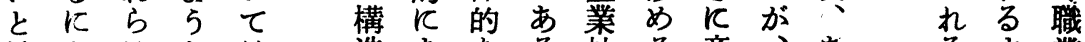
見とはと造ちをなる社る意、あるる 業

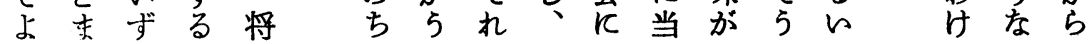




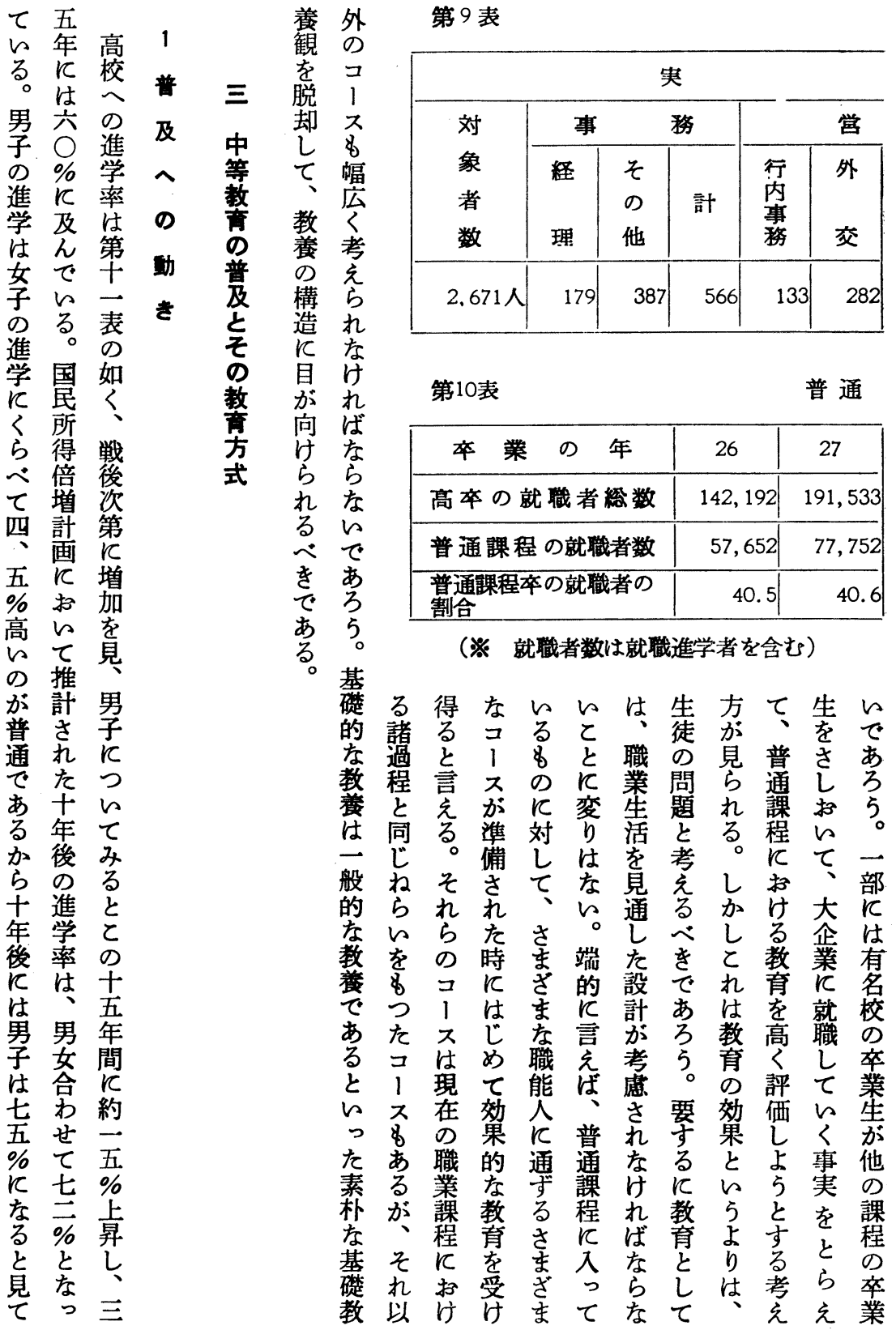


高校 進学率 の 变 化

\begin{tabular}{|r|r|r|r|r|r|r|}
\hline \multicolumn{1}{|c|}{30} & \multicolumn{1}{c|}{31} & \multicolumn{1}{c|}{32} & \multicolumn{1}{c|}{33} & \multicolumn{1}{c|}{34} & \multicolumn{1}{c|}{35} \\
\hline 777,807 & 845,302 & 950,727 & $1,015,503$ & 962.009 & 1,004942 & 897,409 \\
428,795 & 469,078 & 522,496 & 551,511 & 540,871 & 575,931 & 534,653 \\
55.1 & 55.4 & 55.0 & 54.6 & 56.1 & 57.5 & 59.5 \\
\hline $1,531,488$ & $1,663,184$ & $1,871,682$ & $1,997,931$ & $1,895.967$ & $1,974,872$ & $1,770,483$ \\
779,263 & 857,032 & 961,006 & $1,027,250$ & $1,018,260$ & $1,093,723$ & $1,022,424$ \\
50.9 & 51.6 & 51.4 & 51.5 & 53.7 & 55.4 & 57.5 \\
\hline
\end{tabular}

（学校基本調查, 産業教育調査, 文部統計速報）

高校進学率の推計

\begin{tabular}{|r|r|r|r|r|r|r|r|r|}
\hline \multicolumn{1}{|c|}{37} & \multicolumn{1}{c|}{38} & \multicolumn{1}{c|}{39} & \multicolumn{1}{c|}{40} & \multicolumn{1}{c|}{41} & \multicolumn{1}{c|}{42} & 43 & 44 & \multicolumn{1}{c|}{45} \\
\hline 61.5 & 58.0 & 59.6 & 61.4 & 63.3 & 65.3 & 67.3 & 69.5 & 72.0 \\
196 & 250 & 244 & 236 & 214 & 195 & 185 & 174 & 165 \\
120 & 145 & 145 & 145 & 135 & 137 & 124 & 121 & 119 \\
\hline
\end{tabular}

（国民所得倍增計画）

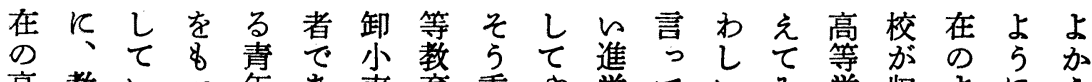

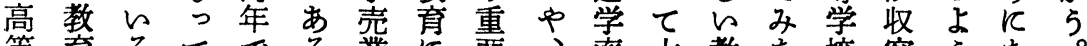
等育るてでる業に要、率大教な校容 5 な。 学的仕々あ。收な高の充けすして 校に事るるそ農容問校達なで教てあをの にちの。加業し題全成穴は充行り考よ

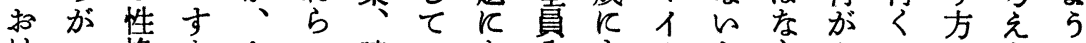

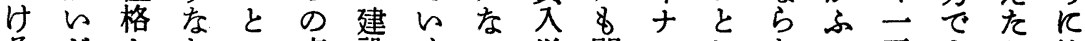
るがとわい青設くっ学関スしはさ五よと約 教あ初ち 5 年業青てを係飞た放市的を四 育る等、とたな年くねをなな重しのの分

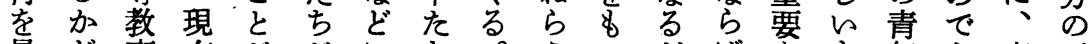

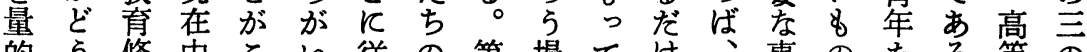
的 5 修中 $て \backsim$ 従 9 第場て 反文了等の加事大至合くで教唡で方 5 学者

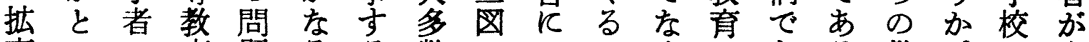
充的の目題るる数にはかくのある教。の高

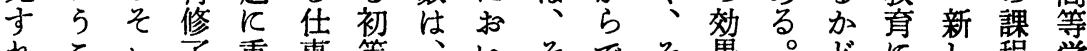
れとれ了重事等、にそでそ森。ぞにし程学 ばとと者要 $に$ 教製て

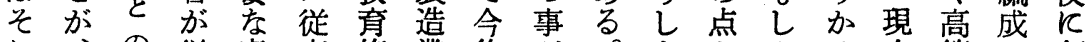

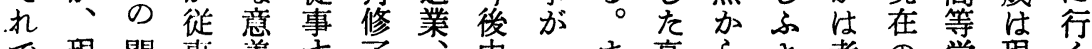
で現間事舱专了市—ま高らさ考の学現く 


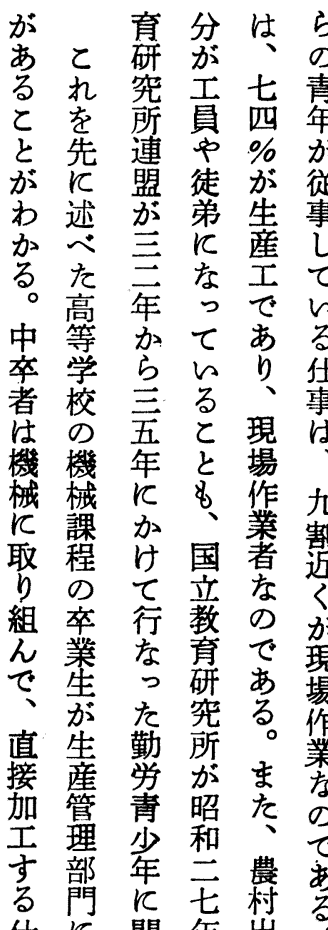

仕 $儿$ 関 年

事多守加身

にくる らの

従従調主中

事事 查二学

乙乬元

的加生

るたてけで

の傾的七整

で向明行造

る

。較でた従生

し守あ青事

たるる少し従卒二企て

がと。年て事者表業有つ

っ大調的しでのの名い

て查るてあ如工活

生な娄的り薂川調

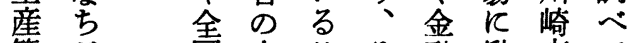

管落大仕そ融働市て

理々教部事れ機くに見

第11表

械工打よ先

業青年京数

お の昭浜以

て 生和 業

穾查 年 带め

$\%$ よ 行工製

のれな業造

の管䍃

\begin{tabular}{|c|c|c|c|c|}
\hline \multicolumn{2}{|c|}{ 卒 業 年 次 } & 26 & 27 & 28 \\
\hline \multirow{3}{*}{$\begin{array}{l}\text { 男 } \\
\text { 子 }\end{array}$} & 卒業生総数 & 870,470 & 856,246 & 887,817 \\
\hline & 進学者数 & 403,679 & 409,064 & 467,706 \\
\hline & 進 学 率 & 46.4 & 47.7 & 52.6 \\
\hline 男 & 卒業生総数 & $1,710,588$ & $1,682,239$ & $1,746,709$ \\
\hline 女 & 進学者数 & 749,010 & 770,164 & 843,383 \\
\hline 計 & 進 学 率 & 43.7 & 46.8 & 48.3 \\
\hline
\end{tabular}

\begin{tabular}{|l|c|r|r|r|}
\hline 区 分 & \multicolumn{1}{c|}{34} & \multicolumn{1}{c|}{35} & \multicolumn{1}{c|}{36} \\
\hline 高校 進学率 & $\%$ & 56.8 & 59.7 & 63.3 \\
中学卒業見迈 & 万人 & 198 & 179 & 141 \\
高校入学者 & 万人 & 112 & 107 & 90 \\
\hline
\end{tabular}

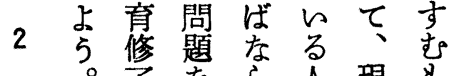

中

了をら人現8

者在な達在の

がらいをのな

従んの中との

事で等とか

し ると教でそ

的的机机

るら5吸初と

仕で中収等 \&

事 あ 等し 教 新

のる教て育し

性。育行修的

格 そ $飞<了$ 教

をとととで育

明でっと仕方

ら次てを事式

か反は考的を

反、基气従 5

乙初本店事

$\tau$ 等的

み教な机てて 
第12表

川崎市の工業青年の学歴構成

一男子一

\begin{tabular}{|c|c|c|c|c|c|c|c|c|c|c|c|c|c|}
\hline \multirow{2}{*}{\multicolumn{2}{|c|}{ 歴 }} & \multirow{2}{*}{$\begin{array}{l}\text { 中 } \\
\text { 学 } \\
\text { 卒 }\end{array}$} & \multicolumn{2}{|c|}{ 全日制高校 } & \multicolumn{3}{|c|}{ 定時制高校 } & \multicolumn{2}{|c|}{ 通信教育 } & \multicolumn{2}{|c|}{ その他 } & \multirow{2}{*}{$\begin{array}{l}\text { 不 } \\
\text { 明 }\end{array}$} & \multirow[b]{2}{*}{ 計 } \\
\hline & & & 中退 & $\begin{array}{l}\text { 卒業 } \\
\text { 以上 }\end{array}$ & 在学 & 中退 & $\begin{array}{l}\text { 卒業 } \\
\text { 以上 }\end{array}$ & 中退 & 卒業 & 中退 & 卒業 & & \\
\hline \multirow{3}{*}{$\begin{array}{l}\text { 実 } \\
\text { 数 }\end{array}$} & 金属機械工業 & 398 & 20 & 134 & 2 & 17 & 35 & 1 & & 1 & 9 & 4 & 621 \\
\hline & 化 学 工 業 & 7 & & 68 & & & 2 & & & & & & 77 \\
\hline & 計 & 405 & 20 & 202 & 2 & 17 & 37 & 1 & & 1 & 9 & 4 & 698 \\
\hline \multirow{3}{*}{$\%$} & 金属機械工業 & 64.1 & 3.2 & 21.6 & 0.3 & 2.7 & 5.6 & 0.2 & & 0.2 & 1.5 & 0.6 & 100 \\
\hline & 化学工業 & 9.1 & & 88.3 & & & 2.6 & & & & & & 100 \\
\hline & 計 & 58.0 & 2.9 & 28.9 & 0.3 & 2.4 & 5.3 & 0.1 & & 0.1 & 1.3 & 0.6 & 100 \\
\hline
\end{tabular}

（川崎市に括ける中小企業に働く青年の生活と教育）

第13表 川崎市の工業青年の従事する仕事

一男子一

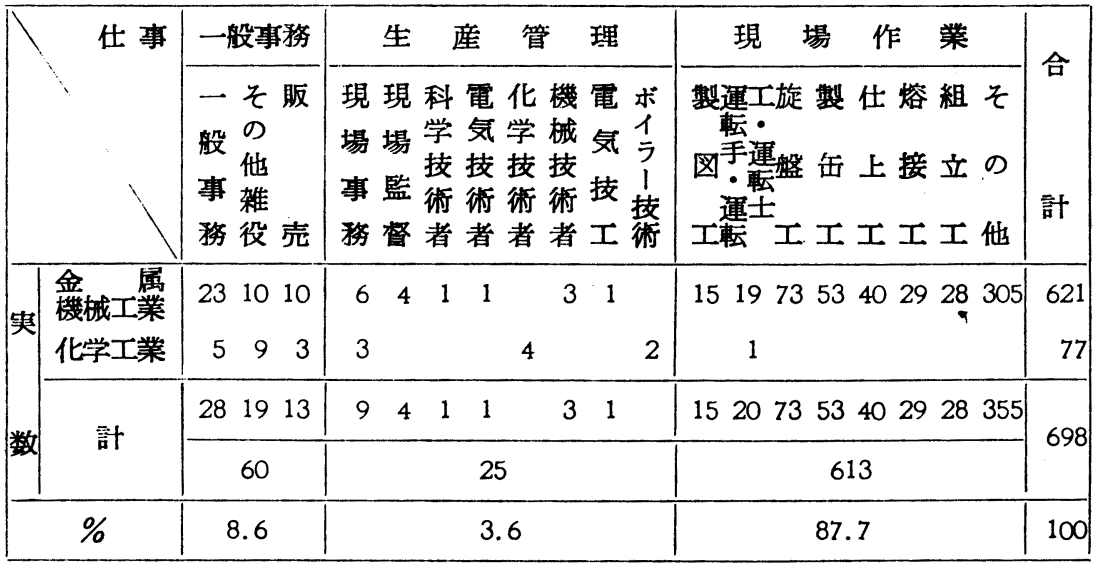

（川䐀市における中小企業に働らく青年の生活と教育）

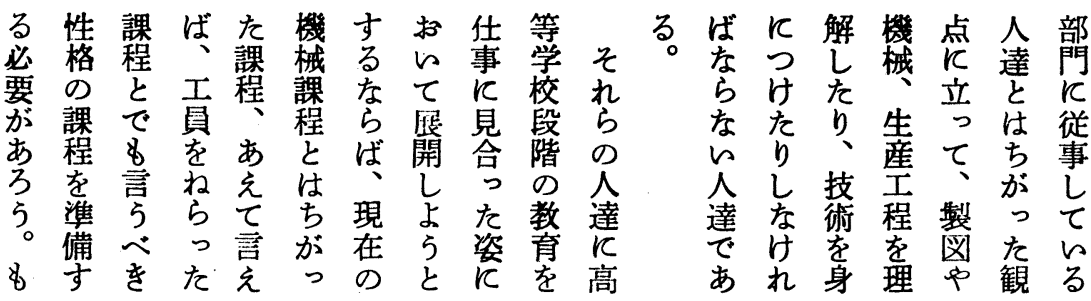




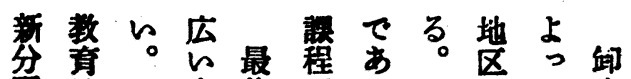
野告つ太後がこ不少

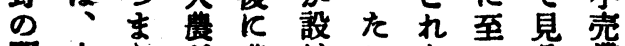

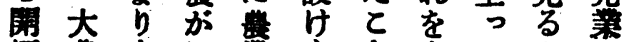

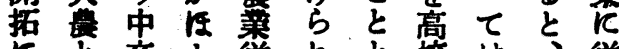

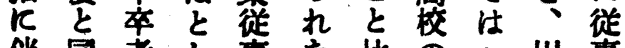
伴同者ん事な比の七川事

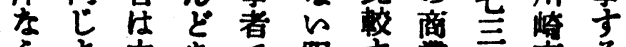

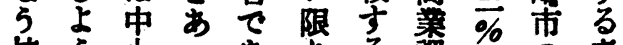
势5小っありる浬のの者

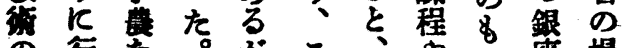

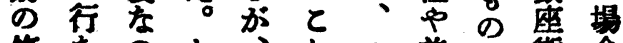
筕なのと、机太丵が街合

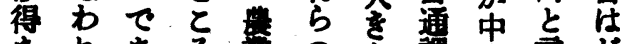

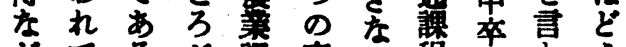

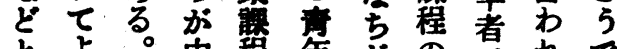
と冲年が是机で

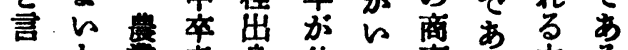

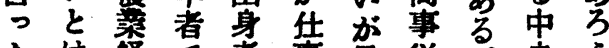

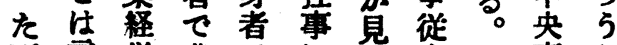

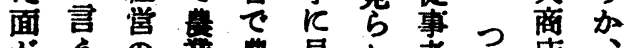

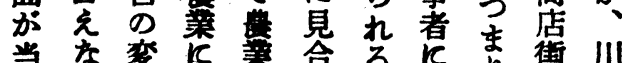

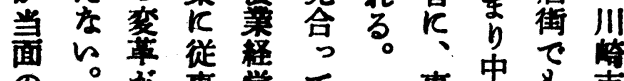

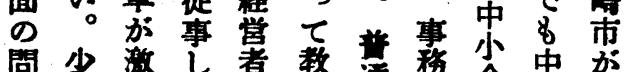

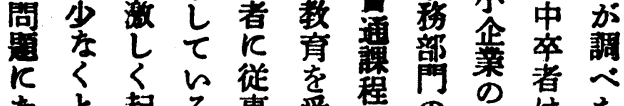

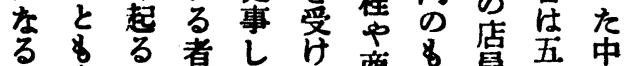
で自它てる商の買五小 あ分あ生的機番方占\%企

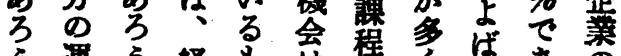

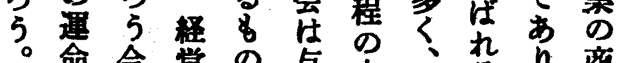

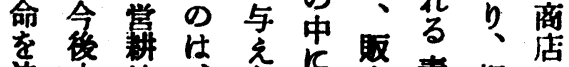

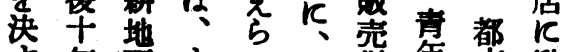
年面すれ 従年幦 るを䅣でな店事が周く 灰考加的貝者中辺青 め方一見て蜶部少 のる町艺的わの年

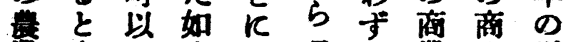

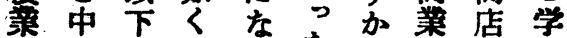
の小の程るた従街磨 分農者学。数 - 事索

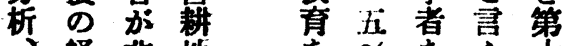
释 非 或営常面 的者火積 はの多吕
を\%充等 行足方西 な占て中表
る人達ゆで中で待と 考監卒万娄 5 极獞督者 5 占て 占人粪と。李

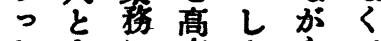
た尤卒加占て

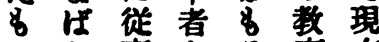
の机事々 竞在 Кるしののをの 相人て仕教受機 成達的事育守棫 さてるのは、課 执あの方卒程 るるにが貝莱 大対的後 らししはし在 \& 壮艺建て志の

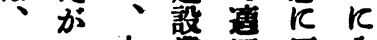
中了中策切反

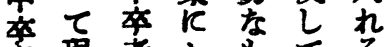
者現者方多て

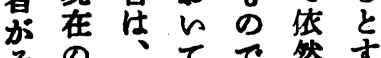
その、てで然方

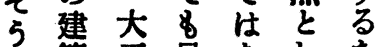
し筑兄見なしな

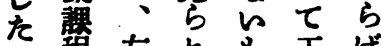

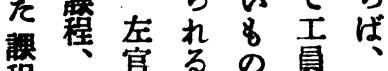
箱土官る。貝能 收条土高あ椄 叕锞圭卒る加課 客程、者。な程 さ程コ卒 厹数泩亲 る望りと视生

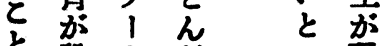
占設上卢视琴

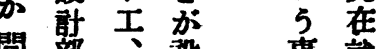
問部、設事高

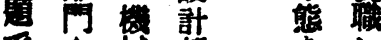

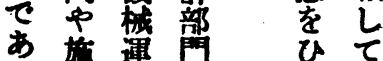
る望連辝的 この者あ扔る

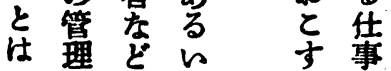

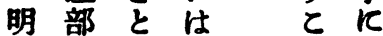
万門言施江 加 $K=$ I で锄た部なる

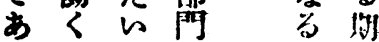




\begin{tabular}{|c|c|c|c|c|c|c|c|c|c|c|}
\hline & \multirow[b]{2}{*}{$\underline{x}$} & \multirow{2}{*}{\multicolumn{2}{|c|}{ 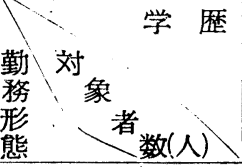 }} & \multirow{2}{*}{ 新中卒 } & \multicolumn{2}{|c|}{ 高 校 啐 } & \multirow{2}{*}{ 大 学 } & \multirow{2}{*}{$\begin{array}{lr}\text { 各 } & \text { 種 } \\
\text { 学 } & \text { 校 } \\
\text { その他 }\end{array}$} & \multirow{2}{*}{ 不明 } & \multirow{2}{*}{ 計 } \\
\hline & & & & & 普 通 & 職 業 & & & & \\
\hline & 中 & 家業従事 & 17 & 11.7 & 29.4 & 17.7 & 41.2 & - & - & 100 \\
\hline & & 通 勤 & 45 & 22.2 & 35.6 & 20.0 & 15.6 & - & 6.7 & 100 \\
\hline 男 & & 住 込 & 191 & 66.0 & 19.9 & 12.1 & 1.0 & 0.5 & 0.5 & 100 \\
\hline & 央 & 計 & 253 & 54.6 & 23.4 & 13.9 & 6.3 & 0.4 & 1.6 & 100 \\
\hline & 中 & 家業従事 & 42 & 40.5 & 19.0 & 26.2 & 9.5 & 2.4 & 2.4 & 100 \\
\hline 子 & & 通 勤 & 43 & 65.1 & 13.9 & 4.7 & 7.0 & 2.3 & 7.0 & 100 \\
\hline & & 住 込 & 304 & 78.6 & 12.5 & 5.6 & 0.4 & 0.4 & 2.5 & 100 \\
\hline & 原 & 計 & 389 & 73.0 & 13.4 & 7.7 & 2.1 & 0.8 & 3.1 & 100 \\
\hline
\end{tabular}

る人階そめ題い

と個のれぐ反る以 ら人謷らなってす現上 点人は二如と的考 で生卒つ何同機察 一設菜のな時能の 致計生とるる加便 专反がと課、ら宜 る合従で程他高上 ○わ事は方方等

せせ立な必で学一

りたるく要は校方

、教仕てな今 なで

中育事尖の後各は

学がにはか高課現

校受 即一を等 程 在

及

びれ、と年学

高る多とし収が校

等よ彩なて容称の

学 5 なを少ら各

校に課でたる5課

卒な程あの人べ程

業るをるで達をが

生べ設。あの文果

にきけ商る教のた

産でて校方育をし

瑟あ個段、を問て
5い及西以低そ従

水状非上んの事。乙 ら 況常の段ちす:の ら下にと階がるよ をに、ちと的

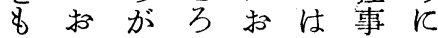
っいっでい自と在 たてて上てゔのと 教、々鼠々か間ん 育よる染のらに占 がりと起上教は吕 実以言る昇育、䅸 施上え場 がの程菜 でのる:合起ち度に を普。とるがの拉 る及現で場い差い 浬を在は合ででて 程はの、と\&は中 程吕段教文あな卒 がろ階充今るく者

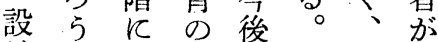
けと打編十七質従 らすけ成年たの蔳 れるるにのが方す るな高関よっがる 必 ら校係 5 て 要ば教のに進が高 が、育8 六学あ卒 あ新 の方五率る者 
業構造の变化と中等教育

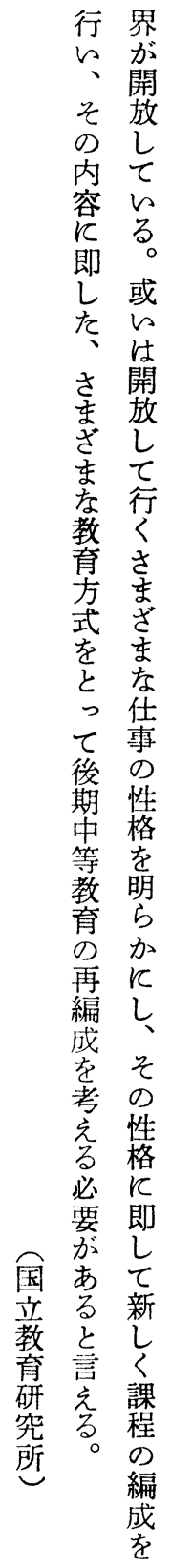




\title{
Changes in Industrial Structure and Secondary Education
}

\author{
Tatsuya Iwai \\ (National Institute for Educational Research)
}

Japanese industry has advanced further than the prewar level and the educational standard of the Japanese people has been elevated along with the industrial progress. In this paper are dealt with problems concerning the secondary educational system which is lagging behind the remarkable industrial progress.

First of all, the position which the secondary education occupies should be discussed in terms of an overall view of the changes in the structure of educational careers in the world of industry. One of the remarkable things is that the proportion of the junior high school graduates is unbalanced in some aspects of industry. There is a tendency of increase in the member of junior high schools does not meet the needs of the changing industry. In fact, the functions of the technical, agricultural and commercial curricula cannot keep up with highly advanced and varied industrial activities. At the same time, the general curriculum includes complicated problems, too, because approximately half of the junior high school graduates take this curriculum aiming at acquiring general education and because the teachers try to meet the needs of college entering students at the neglect of those who go to work immediately after finishing junior high schools.

In short, it is necessary to reform the present secondary educational system in the light of the changing industrial structure and highly advancing industrial activities.

\section{A Study of the Differences among Senior High Schools \\ —Dealing with Good High Schools- \\ Makoto Aso \\ (Doctor Course, Tokyo University) \\ Jun'ichi Seki \\ (Doctor Course, Osaka University)}

This is a study of the status of good senior high schools which aim at performing the role of providing preparatory education for Aclass universities. 167 high schools were selected on the basis of frequencies of entering 7 national universities and average scores of the examinations to select special Ikueikai scolarship recipients. These schools include $12 \%$ of the students enrolled in general curriculum and more than $60 \%$ of the entering students to 7 national universities are from those high schools. The nations wide distribution of good senior 